
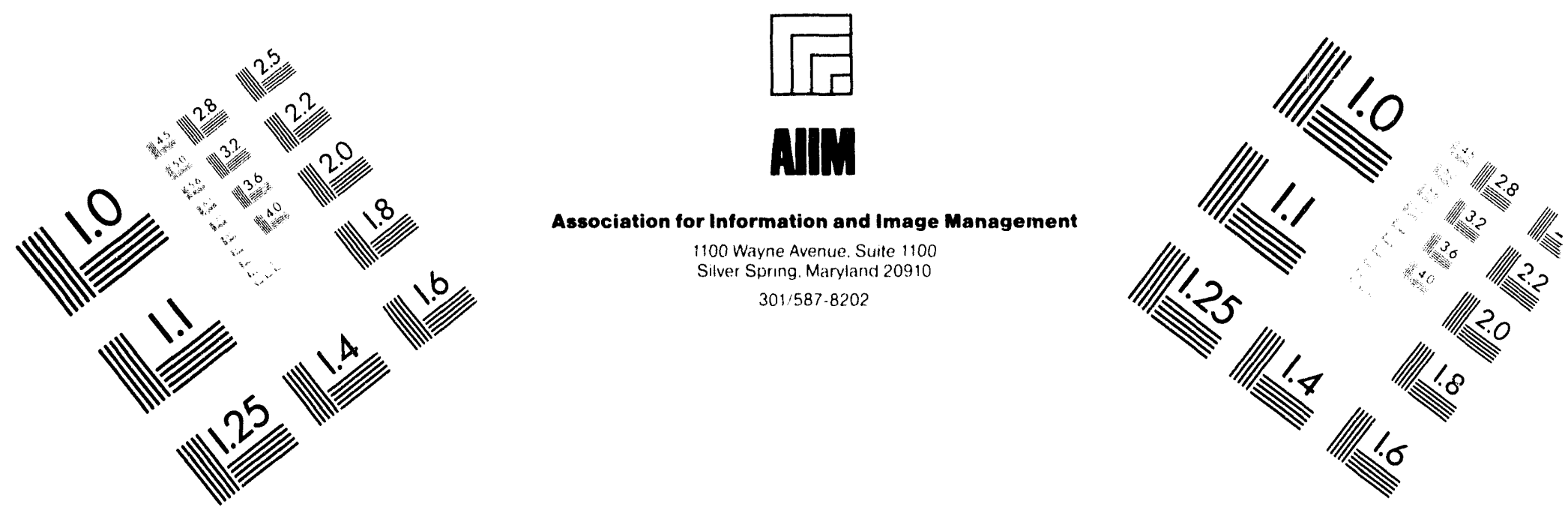

\title{
Centimeter
}

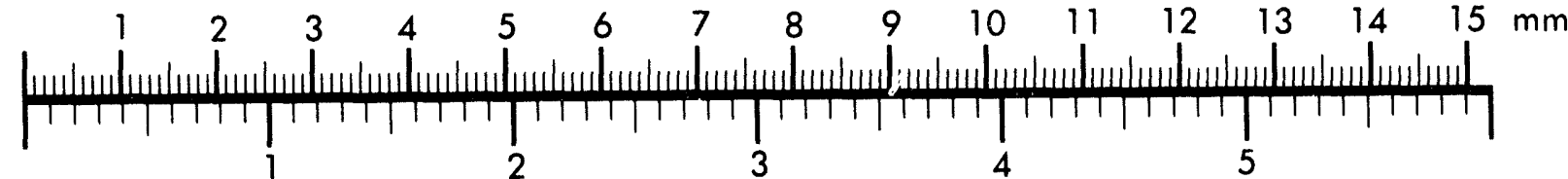

Inches
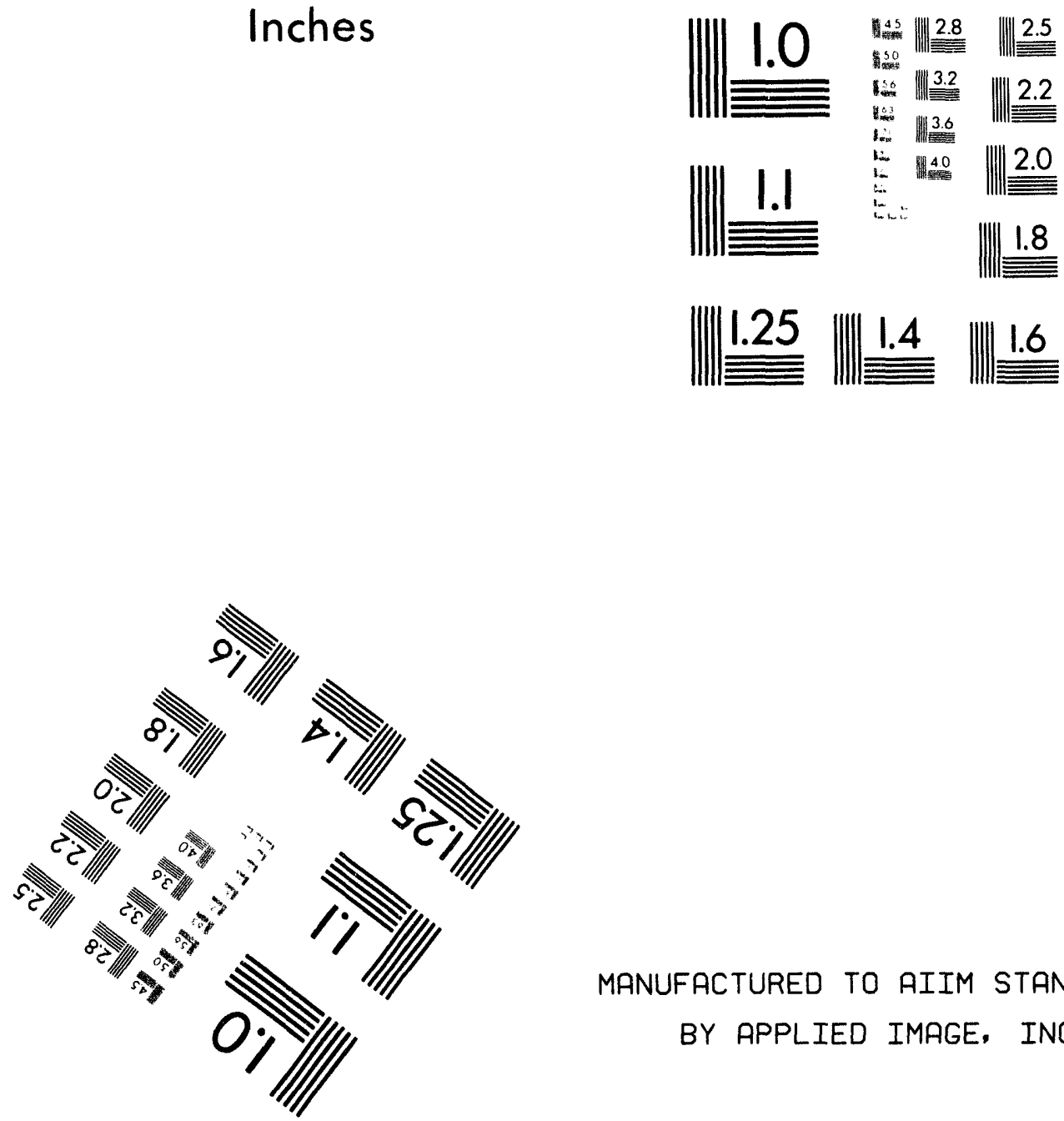

MANUFACTURED TO AIIM STANDARDS

BY APPLIED IMAGE, INC.

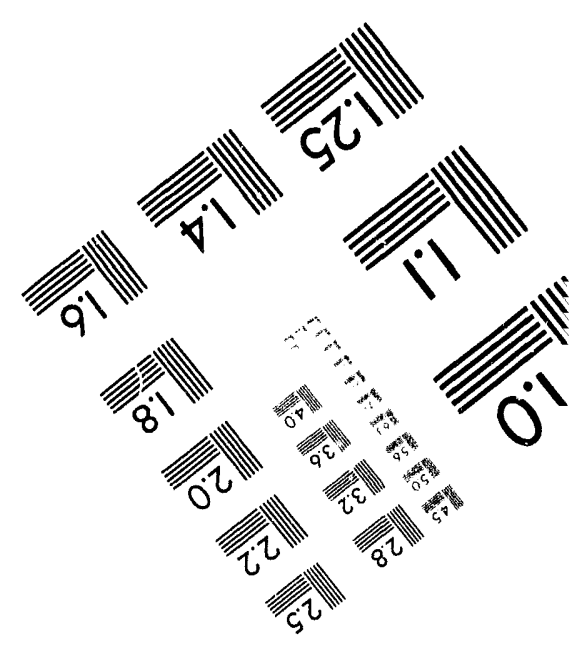



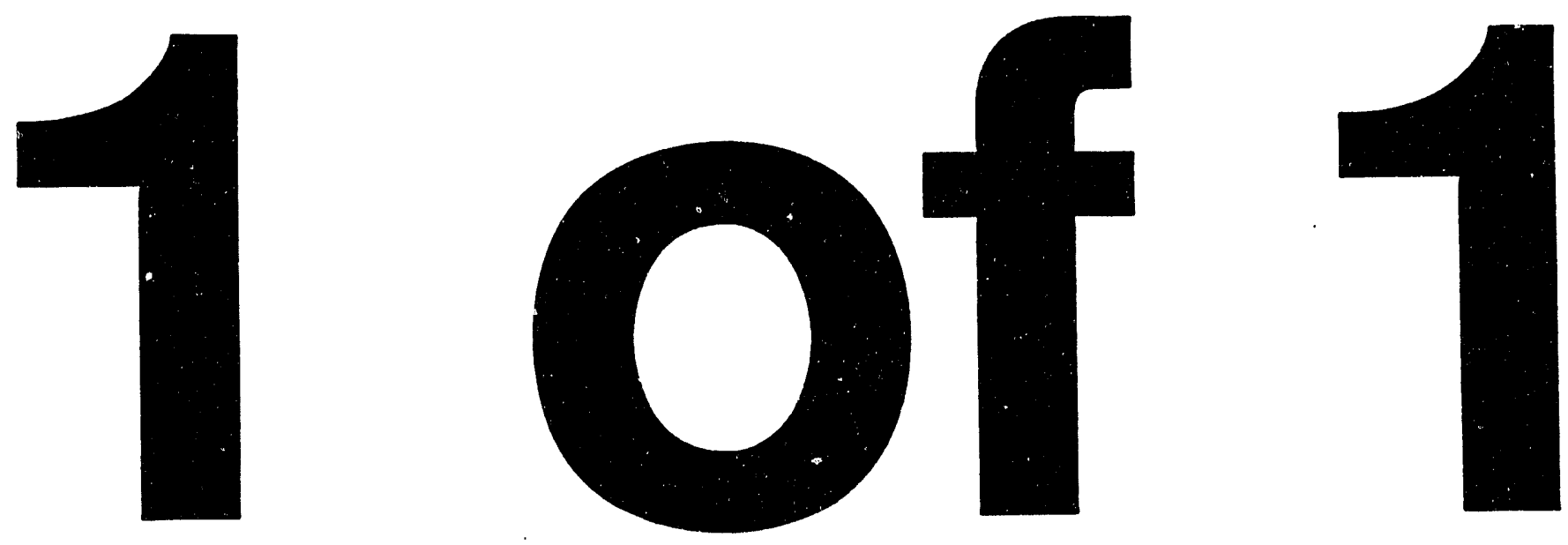


\section{Decision Analysis for Continuous Cover Gas Monitoring of Ferrocyanide Watch List Tanks}

K. D. Fowler

Westinghouse Hanford Company

R. D. Graves

Westinghouse Savannah River Company

Date Published

July 1994

Prepared for the U.S. Department of Energy Office of Environmental Restoration and Waste Management

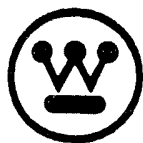

Westinghouse

Hanford Company

Richland, Washington

Hanford Opwrations and Engineering Contractor for the

U.S. Dopartment of Enorgy undor Contract DE-ACO6-87RL10930

Approved for Public Release

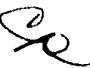




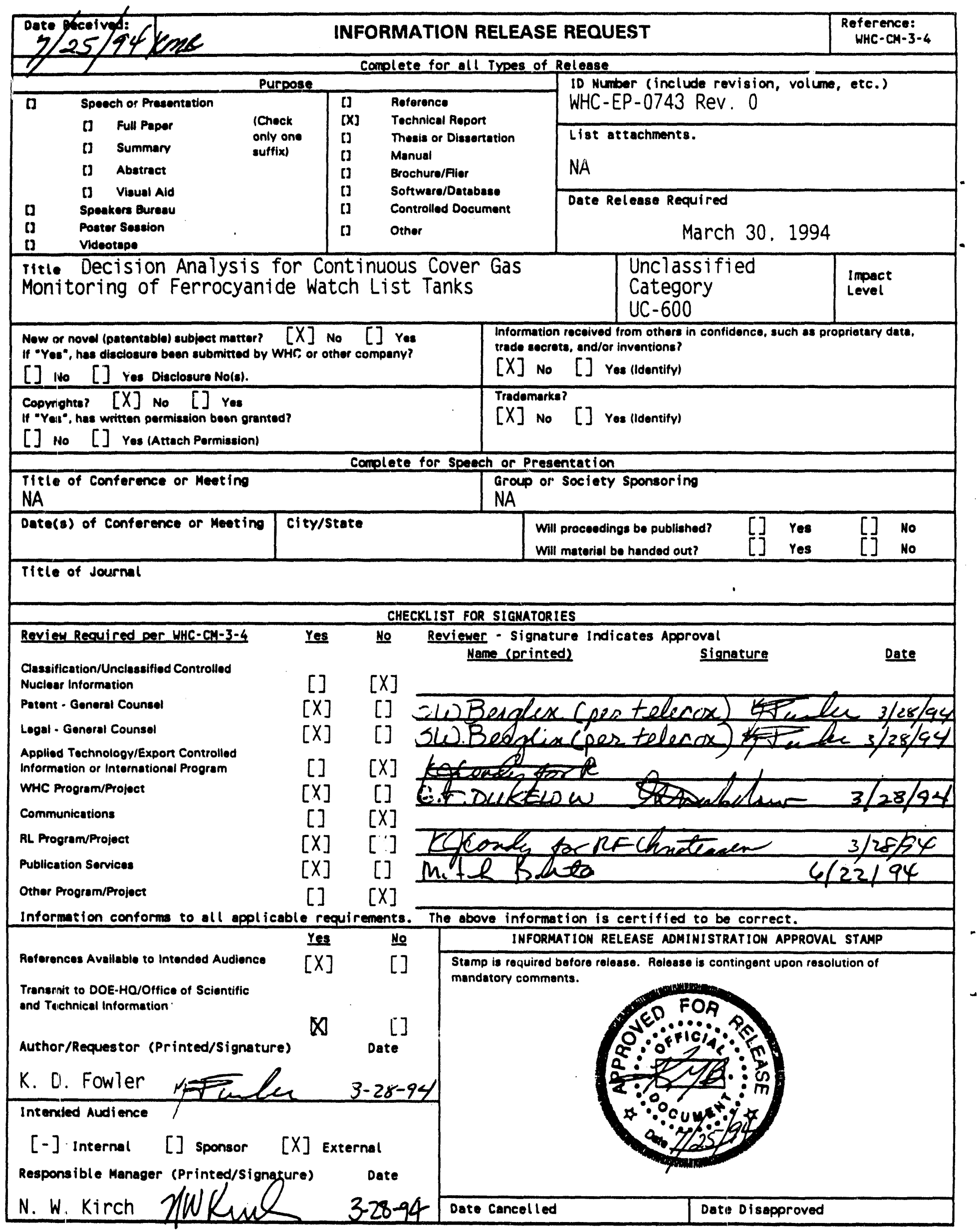




\section{CONTENTS}

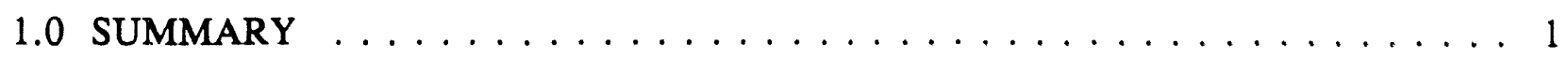

2.0 INTRODUCTION $\ldots \ldots \ldots \ldots \ldots \ldots \ldots \ldots \ldots \ldots \ldots \ldots \ldots \ldots \ldots \ldots$

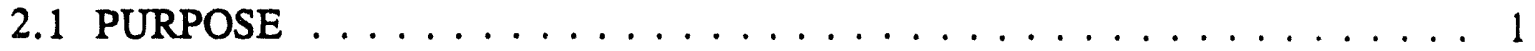

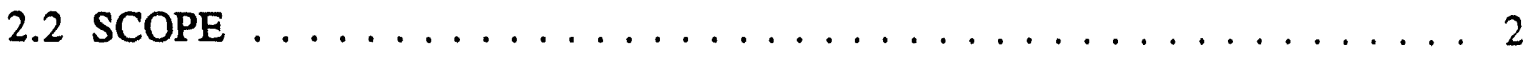

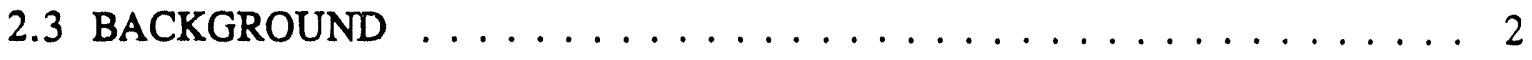

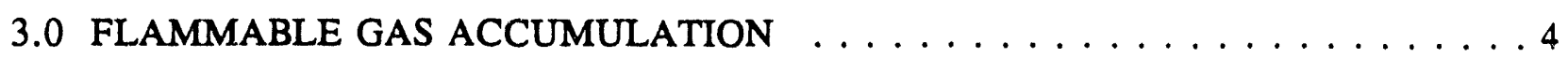

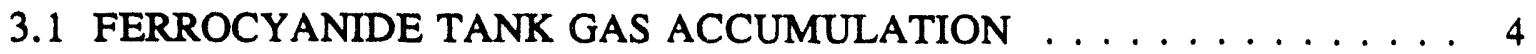

3.2 FERROCYANIDE TANK VAPOR SPACE COMPUTER MODELING . . . 7

3.3 IDENTIFICATION OF TANKS WITH POTENTIAL FLAMMABLE

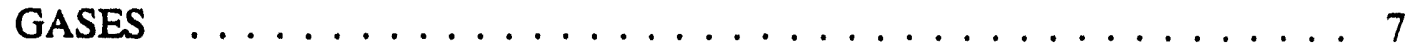

4.0 FERROCYANIDE REACTIONS $\ldots \ldots \ldots \ldots \ldots \ldots \ldots$

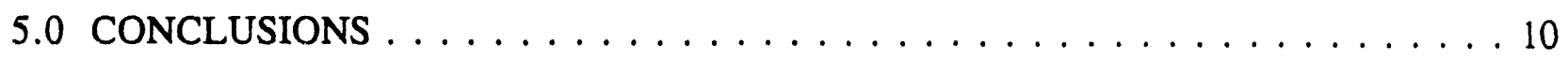

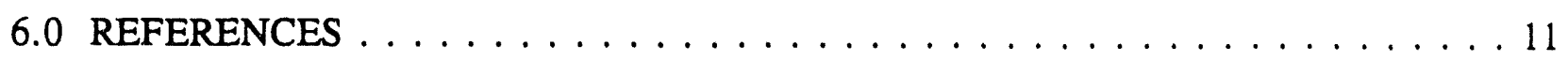
APPENDIX

A FLAMMABLE GASES IN FERROCYANIDE WATCH LIST TANKS $\ldots \ldots \ldots$ A-1

\section{LIST OF TABLES}

1 Ferrocyanide Watch List Tanks $\ldots \ldots \ldots \ldots \ldots \ldots \ldots \ldots \ldots \ldots$

2 Ferrocyanide Tank Vapor Sampling Summary $\ldots \ldots \ldots \ldots \ldots$ 


\section{LIST OF TERMS}

$\mathrm{CH}_{4}$

DNFSB

EDTA

$\mathrm{H}_{2}$

$\mathrm{HCN}$

HEDTA

HEPA

ITS

LFL

LID

$\mathrm{NH}_{3}$

SST

TLV

TOC

USQ
Methane

Defense Nuclear Facilities Safety Board

Ethylenediaminetetraacetic Acid

Hydrogen Gas

Hydrogen Cyanide

Hydroxyethylenediaminetriacetic Acid

High Efficiency Particulate Air

In Tank Solidification

Lower Flammability Limit

Level indicating device

Ammonia

Single-Shell Tank

Threshold Limit Value

Total Organic Carbon

Unreviewed Safety Question 


\subsection{SUMMARY}

The results of modeling studies and gas monitoring, and sludge sample analyses of actual ferrocyanide tank wastes have indicated no need to continuously monitor the vapor spaces in ferrocyanide tanks. This conclusion is based on the following factors:

- Modeling studies of the generation of flammable gases show that 25 percent of the lower flammability limit (LFL) will not be exceeded in ferrocyanide tanks with the exception of tank BY-106 which will not exceed 28 percent of the LFL.

- Sampling for flammable and noxious gases is performed before tank intrusive activities and there has been no indication of an accumulation of flammable gases in the dome spaces of ferrocyanide tanks.

- A study performed on waste aging suggests that the ferrocyanide has degraded in the tanks during the more than 35 years of storage; therefore, the ferrocyanide is not present in concentrations that could support an exothermic reaction. Also, the moisture present in the waste is sufficient to preclude a self-sustaining (propagating) ferrocyanide-nitrate reaction.

- Evaluation of core sample results from Tank 241-C-109 and Tank 241-C-112 support laboratory studies showing that ferrocyanide has degraded and the fuel concentration in the tanks is considerably lower than postulated by flowsheet simulants.

- No gases have been identified that would indicate the occurrence of a ferrocyanide nitrate/nitrite reaction. Additionally, a self-sustaining ferrocyanide nitrate/nitrite reaction is not possible under current and future planned storage conditions.

After reviewing the available information, it is evident that there would be little safety benefit from continuous in-tank vapor monitoring, and the time and commitment of operations schedule and equipment funds are not justified in the face of compeing needs.

\subsection{INTRODUCTION}

\subsection{PURPOSE}

This document evaluates the need for continuously monitoring the headspace vapors in Ferrocyanide Watch List tanks to detect flammable gases or gases that could indicate the 
occurrence of a propagating ferrocyanide-nitrate/nitrite reaction ${ }^{1}$. Concerns that flammable gases might be present in the ferrocyanide tanks led to Defense Nuclear Facilities Safety Board (DNFSB) Recommendation 90-7.3:

"Instrumentation should also be installed to monitor the composition of cover gas in the tanks, to establish if flammable gas is present."

This document addresses some of the concerns presented in Recommendation 90-7.3.

\subsection{SCOPE}

This document pertains to underground waste storage tanks at the Hanford Site that have been identified to potentially contain a significant amount of ferrocyanide compounds. ${ }^{2}$ These Ferrocyanide Watch List taiks are listed in Table 1.

\subsection{BACKGROUND}

During the 1950s, additional waste storage space was required to support the defense mission at the Hanford Site. Between 1953 and 1957, sodium or potassium ferrocyanide and nickel sulfate were added to the wastes remaining from the uranium recovery process to scavenge cesium from the supernatant liquid by precipitating sudium nickel ferrocyanide. Because an excess of sodium ion existed in the waste, the most prevalent precipitate was sodium nickel ferrocyanide. This scavenging process removed soluble cesium. The resultant supernatant liquid was then discharged to cribs or specific retention sites, making more tank storage space available (Postma et al. 1994).

Ferrocyanide sludges were last produced in 1957 and have remained in storage since that time. In subsequent tank farm operations, other wastes were added. For example, concentrated wastes produced by an in-tank solidification (ITS) process were added to Tank 241-BY-104 and other BY Farm tanks. The solidification of ITS evaporator bottoms in Tank 24l-BY-104 has formed a "saltcake" ${ }^{3}$ layer that is approximately 4 feet thick. This added waste could have interacted chemically with the ferrocyanide sludge already in the tanks. Its higher $\mathrm{pH}$ could have dissolved some precipitated ferrocyanide, or solid

\footnotetext{
${ }^{1}$ A propagating chemical reaction occurs when the heat generated within a volume exceeds the rate at which heat is lost from the volume causing an increasing rate of reaction.

${ }^{2}$ Tanks believed to contain more than 1,000 gram moles of ferrocyanide have been classified as Watch List tanks.

${ }^{3}$ Saltcake is the solid mass formed by concentrating waste supernatant and allowing the solution to cool. Saltcake is composed mostly of sodium nitrate, sodium nitrite, sodium carbonate, sodium aluminate, and sodium hydroxide.
} 
ferrocyanide could have removed cesium from the added wastes. Another potentially important effect is the covering of the ferrocyanide sludge with other waste and a resultant resistance to heat transfer. The overlying layer protects the ferrocyanide sludge from drying, but impedes heat transfer. Also, supernatant and interstitial liquid in some tanks was pumped out as part of the Single-Shell Tank (SST) Stabilization Program in order to minimize the loss of liquid to the soil in the event of a tank leak.

Table 1. Ferrocyanide Watch List Tanks.

\begin{tabular}{|c|c|c|c|c|}
\hline \multirow{2}{*}{ Tank 241- } & \multirow{2}{*}{ Vapor sample date } & \multirow{2}{*}{$\begin{array}{c}\text { Tank Center } \\
\text { Line Waste } \\
\text { Depth (inches) }\end{array}$} & \multicolumn{2}{|c|}{ High temperature } \\
\hline & & & ${ }^{\circ} \mathrm{F}$ & ${ }^{\circ} \mathrm{C}$ \\
\hline $\mathrm{BX}-102^{\mathrm{b}}$ & & 42 & 64 & 17 \\
\hline $\mathrm{BX}-106^{b}$ & $06 / 17 / 93$ & 24 & 64 & 18 \\
\hline BY-103 & & 153 & 81 & 27 \\
\hline BY-104 & $10 / 16-30 / 91$ & 155 & 126 & 52 \\
\hline $\mathrm{BY}-105$ & & 190 & 120 & 49 \\
\hline BY-106 & & 241 & 128 & 53 \\
\hline BY-107 & & 104 & 94 & 34 \\
\hline BY-108 & & 90 & 109 & 43 \\
\hline BY -110 & $09 / 27 / 92$ & 152 & 117 & 47 \\
\hline BY -111 & $03 / 25 / 93$ & 174 & 87 & 31 \\
\hline $\mathrm{BY}-112$ & $03 / 26 / 93$ & 113 & 88 & 31 \\
\hline C-108 & $07 / 23 / 93$ & 31 & 77 & 25 \\
\hline$C-109$ & $08 / 26 / 92$ & 31 & 76 & 24 \\
\hline$C-111$ & $08 / 11 / 93$ & 28 & 72 & 22 \\
\hline$C-112$ & $03 / 9-18 / 92$ & 45 & 79 & 26 \\
\hline $\mathrm{T}-107$ & $10 / 22 / 92$ & 73 & 67 & 19 \\
\hline $\mathrm{TX}-118$ & $07 / 28 / 93$ & 134 & 76 & 24 \\
\hline TY-101 & & 50 & 64 & 18 \\
\hline TY-103 & & 66 & 67 & 19 \\
\hline TY-104 & & 24 & 64 & 18 \\
\hline
\end{tabular}

'Hanlon 1994

'Recommended for removal from the Ferrocyanide Watch List (Borsheim et al. 1993) 
Laboratory studies indicate that aging (chemical and radiolytic degradation) has converted the ferrocyanide to lower energy reaction products (Lilga et al. 1993). Thus, the hazard posed by ferrocyanide as a fuel source in SSTs may be significantly less than postulated by flowsheet simulants (Babad et al. 1993). Analyses of core samples taken from Tanks 241-C-109 and 241-C-112 showed total cyanide concentrations about an order of magnitude less than postulated by the historical records (Simpson et al. 1993a, 1993b).

The presence of water in ferrocyanide sludge is important in precluding propagating exothermic reactions because the heat capacity of water is about four times that of dry salts. Wastes samples and simulant sludges have shown high water contents, ranging from 28 wt percent to $70 \mathrm{wt}$ percent. Significant amounts of water remains in tanks that have leaked or have been pumped "dry" (interim stabilized) because the water is held in a fine particle matrix (Postma et al. 1994).

The tanks are vented to the atmosphere through high-efficiency particulate air (HEPA) filters and "breathe" in response to atmospheric pressure changes. No wastes have been added to the SSTs since November 1980 (Postma et al. 1994).

Originally, 24 waste storage tanks on the Hanford Site were believed to contain ferrocyanide compounds at levels of 1,000 gram moles (465 lbs) or more. Since initial classification, a more detailed evaluation of waste transfer records was completed (Borsheim and Simpson 1991). Since that evaluation, four tanks were removed from the Watch List, and of the 20 remaining tanks, an additional two have been recommended for deletion from the list (Borsheim et al. 1993). Removal of these two tanks is pending approval by the U.S. Department of Energy.

\subsection{FLAMMABLE GAS ACCUMULATION}

\subsection{FERROCYANIDE TANK GAS ACCUMULATION}

Ferrocyanide tank waste is expected to produce small amounts of hydrogen gas via radiolysis of water, but at only a small rate due to the relative low fission product contents of the tanks. All ferrocyanide tanks, like most SSTs, are passively ventilated to the atmosphere via individual HEPA breather filters. Air exchanges between the tank and outside air are driven by changes in barometric pressure and ambient temperature. The exchanges cause a small volume of stagnant air to be replaced with fresh air, which helps control the concentration of chemical vapors inside the tanks. Sampling of the ferrocyanide tanks to date has shown only trace amounts of hydrogen and other flammable gases.

Several SSTs emit noxious gases, with ammonia being fairly common. It has been postulated that ferrocyanide tanks could emit hydrogen cyanide $(\mathrm{HCN})$ gas from degradation and aging of the cyanide compounds, although the alkaline conditions of the waste should 
quickly neutralize any $\mathrm{HCN}$ generated. Results to date show less than detectable $(<2 \mathrm{ppm})$ levels of hydrogen cyanide using colorimetric detection tubes. Several tanks have been sampled and analyzed with more sensitive methods and have been reported to have less than 40 parts per trillion hydrogen cyanide. ${ }^{4}$

The normal practice before working around or in a SST is to sample the work space and headspace, if a riser is opened, with a combustible gas analyzer and other gas detection devices (e.g., volatile organic monitor and colorimetric tubes) as directed by Westinghouse Hanford Company Industrial Hygiene. Supplied breathing air initially is used if a tank riser is opened. This sampling control has been included in all safety assessments written for such activities (e.g., vapor space sampling, core sampling, instrument tree installation, etc.).

Several sampling programs were directed at monitoring for hydrogen between January 1974 and September 1989 to confirm that hydrogen concentrations were well below the LFL. Of $161^{5}$ samples known to have been taken from 70 different tanks in 12 tank farms, only one sample was reported to be above the lower detection limit for the analyzing instruments. This sample, which was taken just below the bottom of a riser on Tank 241-B-101 (not a ferrocyanide tank), showed positive with a hydrogen concentration of 0.04 vol percent. It is believed that none of the SST atmospheres contain hydrogen concentrations approaching the LFL (Borsheim and Kirch 1991).

More recent vapor sampling of the ferrocyanide tanks has also detected no flammable gas or vapor concentrations of concern in the tanks. Between October 1991 and August 1993, the vapor spaces of 11 Ferrocyanide Watch List tanks were sampled. ${ }^{6}$ A summary of the results is presented in Table 2.

The fact that no significant concentrations of flammable gases or vapors were detected in any of the tanks is a good indication that there is no accumulation of these gases or vapors. This is further supported by the lack of cyclic surface level fluctuations or temperature profiles indicative of periodic venting of the tanks. Also, no vapors have been identified that indicate the occurrence of a ferrocyanide-nitrate reaction.

${ }^{4}$ Sensitivity of the HCN method is dependent on the sample volume.

${ }^{5}$ Of the 161 hydrogen samples taken, 39 were taken while tanks were connected to an active ventilation system and 122 samples were taken from tanks that were only passively ventilated.

${ }^{6}$ Tanks 241-T-101, 241-BX-110, 241-BX-111, and 241-BY-101 were vapor sampled while still on the Ferrocyanide Watch List. These tanks were removed from the Watch List in July 1993. 


\begin{tabular}{|c|c|c|c|c|c|c|c|c|}
\hline Tank 241- & Dalc anmpled & $\begin{array}{c}\text { Flamman } \\
\text { (percent LFL } \\
\text { ) }\end{array}$ & $\begin{array}{c}\text { Org. Vapor } \\
\text { (ppm) }\end{array}$ & NH, (ppm) & HCN/CN' (ppm) & Hydraines" (ppm) & Nierowe' Geveos (ppon) & Minc. Comments \\
\hline LFLTLV & & & & $160,000 / 25$ & $56,000 / 4.7$ & $67,000 / 0.1$ & $-\overline{3}$ & \\
\hline BY-104 & $10 / 16-30 / 91$ & 1.0 & 37.2 & 250 & ND & $>3.5$ & $>10$ & A, B \\
\hline C-112 & $003 / 02-18 / 92$ & - & - & $<5$ & $<2$ & $<0.2$ & $<2$ & $A, B, C$ \\
\hline C-109 & $08 / 26 / 92$ & 0 & - & $<5$ & $<2$ & $<0.2$ & $<0.5$ & D \\
\hline BY-110 & $09 / 27 / 92$ & o & 350 & $612^{4}$ & $<2$ & $<0.2$ & $<0.5$ & D \\
\hline T-107 & 10/22/92 & - & 24 & 203 & $<2$ & $<0.2$ & $<0.5$ & D \\
\hline T-101 & $02 / 24 / 3$ & 1 & 2.1 & 20.5 & $<2$ & $<0.2$ & $<0.5$ & $\mathbf{D}, \mathbf{E}, \mathbf{F}$ \\
\hline BY-111 & $03 / 25 / 93$ & - & 6.3 & 10.2 & $<2$ & $<0.2$ & $<0.5$ & D \\
\hline BY-112 & $003 / 26 / 93$ & - & 5.9 & 10.0 & $<2$ & $<0.2$ & $<0.5$ & D \\
\hline BX-111 & |06/08/93 & 0 & 3.5 & 69.9 & $<2$ & $<0.2$ & $<0.5$ & D,E \\
\hline BX-110 & -6/09/93 & - & 7.0 & 80.3 & $<2$ & $<0.2$ & $<0.5$ & $\mathbf{D}, \mathbf{E}$ \\
\hline BX-106 & $06 / 17 / 93$ & 0 & 12.0 & 17.9 & $<2$ & $<0.2$ & $<0.5$ & D \\
\hline BY-101 & $06 / 30 / 93$ & - & 20 & 40.0 & $<2$ & $<0.2$ & $<0.5$ & D,E \\
\hline C-108' & 107/23/93 & 0 & 1.2 & $<2$ & $<2$ & $<0.2$ & $<0.5$ & D \\
\hline TX-118' & 07/28/93 & o & 0.3 & 10.1 & $<2$ & $<0.2$ & 0.5 & D \\
\hline C-111' & |08/11/93 & 0 & 0 & $<2$ & $<2$ & $<0.2$ & $<0.5$ & D \\
\hline
\end{tabular}

'Maximum reported values for vapor anmpling effort. Does not include Summe canister anmpling.

Measured using an Induatrial Scientific Corp. Model TMX110 combuntible gas meter

Measured using a Thermo Environmental Modd 580B oreanic vapor monitor

Mensured using colorimetric tubes

shigh reading due to ammonis interference

-Approximation due lo concentration exceoding colorimetric tube range

'Summe canioter cumples also taken for this tank

ND $=$ gone detected

Comments

$A=$ Greatcot value reportod (field monitoring or cryogenic anmple)

$\mathrm{A}=$ Meaned in 2 rioeral 3 devald mo

C = HCN was detectod al 0.4 ppb in ome cryogenic wash solution.

$\mathrm{D}=$ Measured in 1 river $/ 3$ edevations

$E=$ No longer a Ferrocyanide Watch Liat tank

$F=H C N / C N$ value reportod in $\mathrm{mg} / \mathrm{MP}$ 


\subsection{FERROCYANIDE TANK VAPOR SPACE COMPUTER MODELING}

As stated earlier, no flammable or explosive concentrations of vapors have been detected to date in Ferrocyanide Watch List tanks or in any other SST. The adequacy for SST passive breathing to maintain an equilibrium hydrogen concentration below the LFL (4 volume percent) was presented in a study that determined the worst-case estimate of hydrogen concentration within passively ventilated tanks (Garfield 1975).

The ferrocyanide tanks contain significant amounts of radioactive waste material that decay and generate hydrogen gas $\left(\mathrm{H}_{2}\right)$ and ammonia $\left(\mathrm{NH}_{3}\right)$ through radiolysis of water and other compounds. Thermal degradation of organic materials may produce methane $\left(\mathrm{CH}_{4}\right)$ and additional $\mathrm{H}_{2}$ and $\mathrm{NH}_{3}$. Tank corrosion may also produce $\mathrm{H}_{2}$.

The rate of gas accumulation in the tanks depends on three factors: the generation rate, the tank ventilation rate, and the volume of the tank vapor space. The generation rate depends on the amount of radioactive material in the waste and the number of molecules of gas produced per unit of ionizing energy. The latter quantity is referred to as the $G$ value and is usually expressed in molecules of $\mathrm{H}_{2}$ per $100 \mathrm{eV}$ (electron-volts) of ionizing radiation.

Modeling of potential flammable gas accumulations in the ferrocyanide tanks has been done by SST Safety Analysis and results are presented in the appendix of this report. The models, which are based on conservative $G$ values, indicate that the concentration of hydrogen in the passively ventilated tanks will not reach 25 percent of the LFL.

When only passive ventilation is accounted for, the worst-case ferrocyanide tank with respect to vapor space volume and estimated heat load using a conservative G value, 241-BY-106, requires 494 days to reach 25 percent of the LFL. Other ferrocyanide tanks do not reach 25 percent of the LFL. A no ventilation case was also considered for the ferrocyanide tanks. It shows that if the tanks were completely sealed it could take from 6 months (Tank BY-106) up to 11 years (Tank 241-TY-101) to reach 25 percent of the LFL in the tank vapor spaces.

\subsection{IDENTIFICATION OF TANKS WITH POTENTIAL FLAMMABLE GASES}

Four criteria were used to determine whether or not a potentially flammable gaseous mixture might form in the vapor space of a tank. Tanks meeting all four criteria (listed below) were placed on the Flammable Gas Watch List.

1. The waste stored in the tank exhibits, or in the past exhibited, slurry growth type behavior (i.e., an increase in average surface level without an attendant addition of liquid). The waste surface may or may not have behaved 
erratically. Tanks with surface increases attributed to liquid intrusions must have the cause verified beyond all reasonable doubt, to exclude it from having exhibited slurry growth.

2. A surface crust covered the total cross sectional area of the storage tank during the period of growtin and its appearance indicated a structural integrity capable of sealing the surface from escaping gases.

3. The liquid fraction of the waste stored in the tank contains a total organic carbon concentration greater than $3 \mathrm{~g} / \mathrm{L}$. The determination of carbon concentration preferably made from currently available sample data deemed to be reliable. The TRAC model (Jungfleisch 1984) was used to estimate the carbon content where reliable sample data were not available.

4. The tank presently stores, or historically stored, wastes known to contain, or suspected of containing, organic bearing wastes that originated from the B Plant Waste Fractionation process (primarily during stron'iumı recovery). The specific compounds making up the organic fraction are complexing/chelating agents (e.g., HEDTA, EDTA, hydroxyacetic acid, acetic acid) or their degradation products.

None of the ferrocyanide tanks were identified as Flammable Gas Watch List tanks by the screening using these criteria. Continuous flammable gas monitoring will be installed in those tanks that have been identified as Flammable Gas Watch List tanks.

\subsection{FERROCYANIDE REACTIONS}

Continuous vapor monitoring of the dome space of ferrocyanide tanks was proposed as a detection method for a ferrocyanide-nitrate reaction within the waste.

For a chemical reaction in solid materials to be self-sustaining, the reaction must produce enough energy to heat adjacent unreacted solids to a temperature at which the reaction occurs at a rate fast enough that heat cannot be removed as fast as it is generated. Otherwise, a reaction initiated at a local region will die out. 
A technical basis for closing the Ferrocyanide Unreviewed Safety Question and specifying safe storage conditions was developed. The hazard potential for exothermic reactions in the ferrocyanide waste was classified $y$ one of the following levels:

- Level 1 - SAFE

- Concentration of fuel $\leq 8$ wt percent sodium nickel ferrocyanide ${ }^{7}$

- Concentration of water - not limiting

- Concentration of oxidizers - not limiting

- Temperature of waste - not limiting

- Level 2 - CONDITIONALLY SAFE

- Concentration of fuel $>8$ wt percent sod" Im nickel ferrocyanide

- Concentration of water $\geq 0-24$ wt percent ${ }^{8}$

- Concentration of oxidizers - not limiting

- Temperature of waste $\leq 90^{\circ} \mathrm{C}\left(194^{\circ} \mathrm{F}\right)^{9}$

- $\quad$ Level 3 - UNSAFE

- Criteria for SAFE and CONDITIONALLY SAFE are not met.

Based on a comparison of current knowledge of tank contents with the safety criteria, four of the ferrocyanide tanks (241-BX-102, 241-BX-106, 241-C-1i 9 , and 241-C-112) were put into the SAFE category and the remainder were put into the CONDITIONALLY SAFE category pending the completion of core sampling and waste characterization. It is believed that these tanks will be reclassified as SAFE after they have been characterized. No tanks fit the UNSAFE category.

For tanks in the SAFE category, significant reactions are impossible under conditions that would develop under a hypothetical unattended operational mode. Tanks in this category require no special monitoring above that performed for the prudent management of non Watch List tanks.

${ }^{7} \mathrm{Na}_{2} \mathrm{NiFe}(\mathrm{CN})_{6}$ on an energy equivalent basis, calculated on a zero free water basis.

${ }^{8}$ Free water content. The moisture criterion increases linearly from 0 percent at $8 \mathrm{wt} \%$ fuel to $24 \mathrm{wt} \%$ at $26 \mathrm{wt} \%$ fuel.

'The $90{ }^{\circ} \mathrm{C}$ limit was chosen because it provides a safety margin of approximately $30{ }^{\circ} \mathrm{C}$ between the peak waste temperature and the boiling temperature of interstitial liquid where relatively rapid moisture loss could occur. 
For the tanks in the CONDITIONALLY SAFE category, moisture content of the waste is the controlling criterion. The temperature criterion is implicit in the moisture criterion. An unexpected increase in temperature could indicate unexpected exothermic activity in the waste. Thus, prudent management of the waste may include continuous monitoring of the tanks for temperature and perhaps moisture content.

Because all ferrocyanide tanks are classified as SAFE or CONDITIONALLY SAFE, a self-sustaining ferrocyanide-nitrate reaction is not possible and continuous vapor monitoring for reaction products is not recommended.

All of the Ferrocyanide Watch List tanks were evaluated with respect to the safety criteria (Postma et al. 1994). Four of the tanks in Table 1 were categorized as SAFE; and other tanks were categorized as CONDITIONALLY SAFE.

\subsection{CONCLUSIONS}

Modeling studies of the potential for the generation of flammable gases indicate that 25 percent of the LFL is not achieved in ferrocyanide tanks with the exception of tank BY106 which will not exceed 28 percent of the LFL (see Section 3.2).

Results for the vapor samples secured from ferrocyanide tanks have indicated no significant concentrations of flammable gases or vapors. Therefore, there is no need to continuously monitor the tanks for the detection of such concentrations. Evidence of temperature stability does not support speculations of the occurrence of cyclic or periodic venting of the tanks. None of the ferrocyanide tanks were identified in the screening of SSTs for the Flammable Gas Watch List, nor have any indications occurred since that time.

Also, the various vapor sampling efforts for the ferrocyanide tanks has identified no gases that would indicate the possible occurrence of a propagating ferrocyanide nitrate/nitrite reaction.

After reviewing the available information, it is evident that there would be little safety benefit from continuous in-tank vapor and pressure monitoring, and the time and commitment of operations schedule and equipment funds are not justified in the face of competing needs. 


\subsection{REFERENCES}

Babad, H., D. M. Camaioni, M. A. Lilga, W. D. Samuels, and D. M. Strachan, 1993, Tank Waste Chemistry - A New Understanding of Waste Aging, WHC-SA-1694-FP, Westinghouse Hanford Company, Richland, Washington.

Borsheim, G. L., and N. W. Kirch, 1991, Summary of Single-Shell Tank Waste Stability, WHC-EP-0347, Westinghouse Hanford Company, Richland, Washington.

Borsheim, G. L., J. E. Meacham, R. J. Cash, and B. C. Simpson, 1993, Ferrocyanide Safety Program Rationale for Removing Six tanks from the Safety Watch List, WHC-MR-0429, Westinghouse Hanford Company, Richland, Washington.

Borsheim, G. L., and B. C. Simpson, 1991, An Assessment of the Inventories of the Ferrocyanide Watch List Tanks, WHC-SD-WM-113, Rev. 0, Westinghouse Hanford Company, Richland, Washington.

Garfield, J. S., 1975, Maximum Anticipated Hydrogen Concentrations in Underground Tank Atmospheres from Radiolysis of Water, ARH-CD-267, Atlantic Richfield Hanford Company, Richland Washington.

Hanlon, B. M., 1994, Tank Farm Surveillance and Waste Status Summary Report for March 1994, WHC-EP-0182-72, Westinghouse Hanford Company, Richland, Washington.

Jungfleisch, F. M., 1984, TRAC: A Preliminary Estimation of the Waste Inventories in Hanford Tanks Through 1980, SD-WM-TI-057, Rockwell Hanford Operations, Richland, Washington.

Lilga, M. A., M. R. Lumetta, and G. F. Schiefelbein, 1993, Ferrocyanide Safety Project, Task 3 Aging Studies, FY 1993 Annual Report, PNL-8888, Pacific Northwest Laboratory, Richland, Washington.

Postma, A. K., J. E. Meacham, G. S. Barney, G. L. Borsheim, R. J. Cash, M. D. Crippen, D. R. Dickinson, J. M. Grigsby, D. W. Jeppson, M. Kummerer, J. M. McLaren, C. S. Simmons, B. C. Simpson, 1994, Ferrocyanide Safety Program: Safety Criteria for Ferrocyanide Watch List Tanks, WHC-EP-0691, Westinghouse Hanford Company, Richland, Washington. 
Simpson, B. C., G. L. Borsheim, and L. Jensen, 1993a, Tank Characterizarion Data Report: Tank 241-C-112, WHC-EP-0640, Rev. 1, Westinghouse Hanford Company, Richland, Washington.

Simpson, B. C., G. L. Borsheim, and L. Jensen, 1993b, Tank Characterization Data Report: Tank 241-C-109, WHC-EP-0668, Rev. 1, Westinghouse Hanford Company, Richland, Washington. 
WHC-EP-0743

APPENDIX A

FLAMMABLE GASES IN FERROCYANIDE WATCH LIST TANKS 
This page intentionally left blank. 


\section{APPENDIX A}

\section{FLAMMABLE GASES IN FERROCYANIDE WATCH LIST TANKS}

\section{INTRODUCTION}

This appendix describes conservative and realistic estimates of flammable gas concentrations in single-shell Ferrocyanide Watch List tanks. The methodology developed below is used to calculate hydrogen $\left(\mathrm{H}_{2}\right)$ concentrations based on conservative radiolytic generation rates for the ferrocyanide tanks, and conservative and realistic ventilation rates.

This appendix considers hydrogen gas generated by both radiolysis and thermolysis. Corrosion is not believed to contribute significantly to hydrogen production in these tanks.

Flammable gas concentrations, should they surpass the lower flammability limit (LFL), could cause a deflagration or detonation in a tank vapor space. Therefore, it is important to determine if any of the ferrocyanide tanks can reach flammable concentrations. In order to ensure a safety margin, a maximum concentration is specified not to exceed 25 percent of the LFL. The LFL for $\mathrm{H}_{2}$ is 4 vol percent in air.

The rate of gas accumulation in the tanks depends on three factors: the generation rate, the tank ventilation rate, and the volume of the tank vapor space. The generation rate depends on the amount of radioactive material in the waste and the yield of molecules of gas produced per unit of ionizing energy. The latter quantity is referred to as the $G$ value and is usually expressed in molecules of $\mathrm{H}_{2}$ per $100 \mathrm{eV}$ (electron-volts) of ionizing radiation.

\section{SUMMARY AND CONCLUSION}

A method has been developed to predict $\mathrm{H}_{2}$ concentrations in the ferrocyanide tanks over time as a function of generation rates and tank ventilation rates. The method uses heat loads derived from vapor space temperature profiles (Crowe et al. 1993) to determine the volumetric gas generation rate. Calculations were performed using conservative $G$ values for ferrocyanide waste and different tank ventilation rates.

The thermal production of $\mathrm{H}_{2}$ is also calculated. Thermal production requires the presence of organic molecules in the tanks. These molecules are the original chelators, EDTA and HEDTA, and their radiolytic degradation products (Meisel 1991, 1993). The generation rate for thermal production is conservatively based on the experimentally estimated rate for tank 241-SY-101. Thermal production is strongly dependent on temperature and the type and quantity of organic material present in the tank. In applying the SY-101 results to other waste tanks, the SY-101 rate was conservatively modified to account for the strong dependence on ternperature and on the total organic carbon (TOC) content. The estimated 
thermal generation rate used in these calculations is higher than the experimentally measured rates for the individual radiolytic degradation products of EDTA and HEDTA.

Calculations performed using this method for the Ferrocyanide Watch List tanks show that with conservative $G$ values and with conservative ventilation rate assumptions only one of the tanks, BY-106, exhibits gas concentrations exceeding 25 percent of the LFL. The tank reaches a maximum of 28 percent of the LFL. When instrument purge air is included in the model, the calculated $\mathrm{H}_{2}$ concentrations in the tanks are consistent with values measured in the tanks.

Calculations were also performed with no tank ventilation (i.e. completely sealed tank). Under these conditions some of the tanks required as much as 11 years to reach 25 percent of the LFL.

In the case of Tank 241-BY-106, the tank with the highest heat load and smallest vapor space, the highest measured $\mathrm{H}_{2}$ concentration was 2.4 percent of the LFL (Farley 1991) with an error of $+/-25$ percent. Using the calculated heat load for this tank the $\mathrm{H}_{2}$ generation can be estimated. The estimated radiolysis $G$ value, based on 3 percent of the LFL sample, is between $0.01-0.08$ molecules $/ 100 \mathrm{eV}$. The lower limit corresponds to passive breathing and the upper limit to a $60 \mathrm{CFH}$ ventilation rate.

The safety basis for combustible gases in the ferrocyanide tanks is to maintain the concentration below the LFL. To provide a safety margin, the maximum allowable concentration is specified by administrative control to be no greater than 25 percent of the LFL.

Based on this analysis, it is unlikely that any of the ferrocyanide tanks could obtain gas concentrations exceeding 25 percent of the LFL. The $G$ value assumptions required to obtain $\mathrm{H}_{2}$ concentrations exceeding 25 percent of the LFL are inconsistent with the range of $G$ values predicted from studies of solutions similar to the waste in the ferrocyanide tanks and with measured flammable gas concentrations (Henrie 1986 and Meisel et al. 1991).

\section{CALCULATION METHOD}

The overall approach is to develop a set of equations based on mass balance that describes the time dependent concentration of $\mathrm{H}_{2}$ gas in the tank vapor space. These equations are then used to predict the total gas generation rate, the maximum $\mathrm{H}_{2}$ concentration in the vapor space, and the time required to reach 25 percent of the LFL for each tank. The equations are evaluated numerically using Microsoft EXCEL ${ }^{1}$ for a conservative $G$ value and different ventilation rates. Results are compared to sample data obtained using combustible gas meters

${ }^{1}$ Microsoft EXCEL is a registered trademark of Microsoft, Inc. 
in the field for the various tanks. Finally, the equations are used to back calculate a range of $G$ values consistent with measured values.

The calculation of the rate of change of the gas concentration in the tank vapor space is formulated from the mass balance equation:

$$
\Delta V=V_{\text {in }}-V_{\text {our }}
$$

Assuming uniform and complete mixing, equation 1 can be expressed in differential form as:

$$
\frac{d V}{d t}=V_{B_{2}}-\left[V_{H_{2}}+Q\right] \frac{V(t)}{V_{C V}}
$$

Where:

$$
\begin{aligned}
\mathrm{V}(\mathrm{t}) & =\text { instantaneous volume of hydrogen }(\mathrm{L}) \\
\mathrm{V}_{\mathrm{H} \mathrm{2}} & =\text { volume production rate }(\mathrm{L} / \text { day) } \\
\mathrm{V}_{\mathrm{CV}} & =\text { headspace volume }(\mathrm{L}) \\
\mathrm{Q} & =\text { ventilation flow rate }(\mathrm{L} / \text { day) }
\end{aligned}
$$

The solution to this equation gives the following relation for the volumetric concentration:

$$
\frac{V(t)}{V_{C V}}=\left(\frac{V_{0}}{V_{C V}}-\frac{V_{H_{2}}}{V_{H_{2}}+Q}\right) e^{-\frac{V_{B_{2}}+Q}{V_{C V}} t}+\frac{V_{H_{2}}}{V_{H_{2}}+Q}
$$

where the last term is the steady state $\mathrm{H}_{2}$ concentration and $\mathrm{V}_{0} / \mathrm{V}_{\mathrm{CV}}$ is the initial concentration. $\mathrm{H}_{2}$ generated in the waste is primarily from the radiolysis of water and thermal production from radiolytic degradation products of the original organic chelators EDTA and HEDTA (Meisel 1993). Thus, the total generation rate in the waste is

$$
\left.V_{H_{2}}=V_{H_{2}}(\text { Radiolysis })+V_{H_{2}} \text { (Thermal Production }\right)
$$

The volume production rate of $\mathrm{H}_{2}$ due to radiolysis is calculated from the radioactive decay heat load in the tank. Given a radiolytic $\mathrm{G}\left(\mathrm{H}_{2}\right)$ value for the waste in the tanks, the gas generation rate is 


$$
\dot{V}_{H_{2}}=H \times G\left(H_{2}\right) \times F(T)
$$

where:

$$
\begin{aligned}
\mathrm{F} & =\text { units conversion factor, } \\
\mathrm{G}\left(\mathrm{H}_{2}\right) & =\text { molesules of } \mathrm{H}_{2} \text { generated per } 100 \mathrm{eV} \text { of ionizing radiation, } \\
\mathrm{H} & =\text { heat load in } \mathrm{W} \text { (Joules/sec) } \\
\mathrm{T} & =\text { vapor space temperature in degrees Kelvin }
\end{aligned}
$$

The units conversion factor, $\mathrm{F}$, is given by:

$$
\begin{gathered}
F=\frac{\text { Joule }}{s} \times \frac{\text { molecules }}{100 \mathrm{eV}} \times \frac{22.4 \mathrm{LH}_{2}}{6.02 \times 10^{23} \text { molecules } \mathrm{H}_{2}} \times \frac{T}{273 \mathrm{~K}} \\
\times \frac{6.24 \times 10^{18} \mathrm{eV}}{\text { Joule }} \times 8.64 \times 10^{4} \frac{\mathrm{s}}{d a y} \\
F=7.35 \times 10^{-4} \times T
\end{gathered}
$$

\section{ESTIMATION OF HEAT LOADS}

Accurate determination of the generation rate (Equation 5) depends on the accurate determination of radioactive heat load in the tanks. Previous calculations have determined the heat load based on estimates of the radionuclide content of the tank. Uncertainties in estimations of the radionuclide content of the tanks lead to uncertainties in the gas generation rate.

The approach taken in this report is to use heat loads for the ferrocyanide tanks that were estimated using a method that relates temperatures in the vapor space of tanks without active ventilation to the steady state heat rate. The method briefly described below provides a conservative but more accurate estimate.

Seasonal atmospheric temperature variations are observed in the vapor space temperature data with a characteristic phase shift and amplitude damping with respect to atmospheric temperatures (Crowe et al. 1993). This observation permits the calculation of heat 
transmission rate through the soil over the tank directly from the measured vapor space temperatures.

Using the assumption that the vapor space is uniform, a single dimensional heat flux through the soil overburden was calculated. A conservative estimate was made of the fraction of the total heat loss from the tank expected to take place through this upward pathway. The calculated heat flux was adjusted by this fraction to give the total tank heat load.

This method of calculating the heat load is believed to be conservative for flammable gas calculations in that it overestimates the heat load

\section{ESTIMATION OF G VALUES}

Another important parameter for calculating the gas accumulation rate in the tank is the $G$ value. Because ferrocyanide tank solius contain excess amounts of highly soluble nitrate salts, it is expected that the liquid associated with the solids is saturated in nitrates. Nitrates are known to suppress $G$ values.

A saturated solution of sodium nitrate at room temperature has a specific gravity of about 1.36. Of the ferrocyanide tanks, Tank $241-\mathrm{BY}-106$ has the lowest specific gravity of 1.35 . From Figure 4-5 of Henrie (1986), for sodium nitrate solutions with specific gravity of 1.35 , the $\mathrm{G}$ value is 0.025 molecules $\mathrm{H}_{2} / 100 \mathrm{eV}$. The choice of $\mathrm{G}$ value of the water is based on the content of the ferrocyanide waste. The solutions have water contents around $750 \mathrm{ml}$ water/L solution (Kummerer 1993). From Figure 4-6 of Henrie (1986), this gives a $G$ value around 0.038 molecules $\mathrm{H}_{2} / 100 \mathrm{eV}$.

Meisel (1991) found a $G$ value of 0.031 for a solution that contained a mixture of dissolved inorganic components of Hanford Site wastes. The nitrate concentration of that solution was 2.79 molar, and the nitrite concentration was 2.2 molar. The nitrate value is somewhat lower than most of the ferrocyanide tank supernate (Meisel et al. 1993), but the $G$ value is generally found consistent with those found for nitrate solutions in Henrie (1986).

A study of the radiolytic generation of $\mathrm{H}_{2}$ in synthetic waste (Meisel 1991), tested the effect of the presence of organic compounds in solution on the radiolytic $G$ value. The results are given in Table B3-1 of Meisel (1993) for a number of the organic chemicals likely to be present in Hanford waste. At $30{ }^{\circ} \mathrm{C}$ these range from 0.036 molecules/100 eV for a solution containing the organic additive citrate to 0.048 molecules $/ 100 \mathrm{eV}$ for the additive glycolate. At $60{ }^{\circ} \mathrm{C}$ the range was 0.037 molecules $/ 100 \mathrm{eV}$ for citrate to 0.080 molecules $/ 100 \mathrm{eV}$ for an irradiated organic additive consisting of $0.065 \mathrm{M}$ EDTA, $0.065 \mathrm{M}$ HEDTA, and $0.1 \mathrm{M}$ citrate. 
- To a good approximation Meisel (1991) found the generation rate, $\mathrm{G}\left(\mathrm{H}_{2}\right)$, to vary linearly with molar concentration of organic:

$$
G\left(H_{2}\right)=G\left(H_{2}\right)_{[R H=O]}+R_{X} \times[R H]
$$

where:

$$
\begin{aligned}
R_{x} & =\text { conversion efficiency } \\
{[R H] } & =\text { molar concentration of organic } x .
\end{aligned}
$$

The efficiencies, $\mathbf{R}_{\mathbf{x}}$, for the organic additives is given in Meisel 1993, Table B3-1. The organic additive EDTA with a value of 0.167 at $30^{\circ} \mathrm{C}$ and 0.2 at $60{ }^{\circ} \mathrm{C}$ is used in these calculations. The base generation rate was 0.031 at $30^{\circ} \mathrm{C}$ and 0.033 at $60{ }^{\circ} \mathrm{C}$.

Since the waste temperatures in the ferrocyanide tanks are less than $60{ }^{\circ} \mathrm{C}$, the lower efficiency, 0.167 , was used to calculate $\mathrm{G}\left(\mathrm{H}_{2}\right)$ for the tanks.

\section{ESTIMATION OF THERMAL GENERATION RATE}

Thermal generation of $\mathrm{H}_{2}$ has been studied experimentally by Meisel et al. (1993). For simulated waste solutions containing $0.065 \mathrm{M}$ EDTA, $0.065 \mathrm{M}$ HEDTA, and $0.1 \mathrm{M}$ citrate at $60{ }^{\circ} \mathrm{C}$, the thermal generation rate of $\mathrm{H}_{2}$ was estimated to be $8.3 \times 10^{-9} \mathrm{moles} / \mathrm{min}$. This solution corresponds to about 1.7 percent total organic carbon (TOC). On a dry basis this corresponds to about 4 percent TOC. Thermal generation rates increase with temperature and TOC. The ferrocyanide tanks have a lower organic carbon content and are at lower temperatures.

\section{MAXIMUM ACHIEVABLE VAPOR SPACE CONCENTRATION}

If we consider the solution of the mass balance equation for $\mathrm{H}_{2}$ accumulation, Equation 3, for very long times, the $\mathrm{H}_{2}$ concentration approaches

$$
\frac{V(\infty)}{V_{C V}}=\frac{V_{H_{2}}}{\left(V_{H_{2}}+Q\right)}
$$

The minimum generation rate that would cause a full 75 foot diameter waste tank to reach the LFL of 4 percent for hydrogen in air can be calculated using Equation 9. 


$$
\begin{aligned}
\frac{V_{H_{2}}}{V_{H_{2}}+Q} & =0.04 \\
V_{H_{2}} & =\frac{4 Q}{96}\left(\frac{L}{d a y}\right)
\end{aligned}
$$

\section{TIME TO ACHIEVE 25 PERCENT LFL}

The acceptance criteria for flammable gases is 25 percent of the LFL or a 1 vol percent $\mathrm{H}_{2}$ concentration in the tank vapor space. The time to reach 25 percent LFL for tanks that reach a maximum concentration more than 25 percent LFL can be determined by setting the left hand side of equation 3 equal to 0.01 and solving for $t$ :

$$
t(25 \% L F L)=-\frac{V_{C V}}{\left(V_{H_{2}}+Q\right)} \ln \left(\frac{0.99 V_{H_{2}}-0.01 Q}{V_{H_{2}}-\frac{V_{0}}{V_{C V}}\left(V_{H_{2}}+Q\right)}\right)
$$

\section{ESTIMATE OF VENTILATION RATES}

Another important quantity affecting the gas accumulation in the tanks is the ventilation rate. Any generation rate can be accommodated if sufficient ventilation is available. For the ferrocyanide tanks, ventilation flow is available from atmospheric breathing. Purge air to instruments such as the level indicating devices (LID) may also add to the ventilation rates in the tanks, for those tanks with operating LIDs.

Pressure differences between the outside atmosphere and the tank vapor space because of the generation of gases and vapors and because of barometric changes are relieved by atmospheric breathing. Each tank has a dedicated breather riser, which is equipped with a high efficiency particulate air (HEPA) filter to reduce loss of radioactive particulate from the tank. Additionally, small openings and cracks in the pit covers and unsealed risers allow some air to pass unfiltered between the tank and the atmosphere.

Changes in the barometric pressure cause passively ventilated storage tanks to exchange an average of 0.45 percent of the air in their vapor space with the atmosphere per day (Crippen 1993).

Dry instrument air may be introduced into the tanks at a rate of 50 to $60 \mathrm{ft}^{3} / \mathrm{hr}$ (CFH) at, for example, the LID level gauge housing in order to prevent condensation of moisture in the housing. For the ferrocyanide tanks, this amounts to 1.1 to 2.6 percent of the vapor space volume per day. 
The ventilation rate, $Q$, in the tanks can be estimated for the case of atmospheric breathing only to be (Crippen 1993)

$$
Q=0.0045 \times V_{c V}
$$

The ventilation rate in the tanks for both atmospheric breathing and purge air is estimated to be

$$
\begin{aligned}
Q=0.0045 \times V_{C V} & +\frac{50 f^{3}}{h r} \times 28.317 \frac{L}{f^{3}} \times 24 \frac{h r}{d a y} \\
& =0.0045 \times V_{C V}+3.4 \times 10^{4} \frac{L}{d a y}
\end{aligned}
$$

\section{RESULTS}

The results of the calculations for the ferrocyanide tanks are presented in Tables A-1 through A-3. Table A-1 lists relevant data for each tank along with vapor spare volume, and the units conversion factors. The vapor space volume was calculated by assuming that the dome volume could be represented by an ellipsoid with a semi-major axis equal to half of the tank diameter ( $d / 2)$ and a semi-minor axis equal to the dome height $(\mathrm{h})$. With these assumptions the dome volume is given by

$$
\text { Dome Volume }=\frac{h}{6} \pi d^{2}
$$

Using equation 14 for the dome volume, the vapor space volume is given by

$$
C_{C V}=\frac{(L-x)}{4} \pi d^{2}+\text { Dome Volume }
$$

where:

$$
\begin{array}{lll}
\mathrm{L} & = & \text { tank well height } \\
\mathrm{x} & = & \text { waste tank height }
\end{array}
$$

Vapor space temperatures fall in the narrow range $17^{\circ} \mathrm{C}-27^{\circ} \mathrm{C}\left(62-80^{\circ} \mathrm{F}\right)$ so that the unit conversion factor is roughly constant for the tanks. Tank 241-BY-106 is the worst case 
for gas generation and accumulation of the ferrocyanide tanks because it has the highest heat load and smallest vapor space volume.

Table A-2 shows the results of the calculations for radiolytic $G$ values ranging from 0.055 to 0.083 molecules/ $100 \mathrm{eV}$ and the thermal generation rate based on $8.3 \times 10^{-9} \mathrm{M} / \mathrm{Min}$ discussed above. With these generation rates, the table shows that only one of the tanks (BY-106) reaches 25 percent of the LFL. 
Table A-1. Ferrocyanide Tank Data.

\begin{tabular}{|l|c|l|l|l|l|l|}
\hline Tank 241- & $\begin{array}{c}\text { Waste volume } \\
(\mathrm{kgal})^{\mathrm{a}}\end{array}$ & $\begin{array}{c}\text { Waste } \\
\text { height (ft) }\end{array}$ & $\begin{array}{c}\text { Vapor space } \\
\text { volume (L) }\end{array}$ & $\begin{array}{c}\text { Vapor space } \\
\text { temperature } \\
\left({ }^{\circ} \mathrm{F}\right)^{\mathrm{b}}\end{array}$ & $\begin{array}{c}\text { Units } \\
\text { conversion } \\
\text { factor }\end{array}$ & $\begin{array}{c}\mathrm{H}_{2} \text { Gen. } \\
\text { Radiolysis } \\
\text { Rate (G) }\end{array}$ \\
\hline BX-102 & 96 & 3.53 & $2.81 \mathrm{e}+06$ & 64.0 & 0.22 & 0.071 \\
\hline BX-106 & 46 & 2.02 & $3.00 \mathrm{e}+06$ & 63.3 & 0.22 & 0.083 \\
\hline BY-103 & 400 & 2.74 & $2.52 \mathrm{e}+06$ & 70.2 & 0.23 & 0.061 \\
\hline BY-104 & 406 & 2.92 & $2.50 \mathrm{e}+06$ & 78.5 & 0.23 & 0.074 \\
\hline BY-105 & 503 & 15.86 & $2.13 \mathrm{e}+06$ & 78.0 & 0.23 & 0.061 \\
\hline BY-106 & 642 & 20.08 & $1.60 \mathrm{e}+06$ & 81.0 & 0.23 & 0.061 \\
\hline BY-107 & 266 & 8.68 & $3.03 \mathrm{e}+06$ & 79.3 & 0.23 & 0.064 \\
\hline BY-108 & 228 & 7.53 & $3.17 \mathrm{e}+06$ & 80.3 & 0.23 & 0.066 \\
\hline BY-110 & 398 & 2.68 & $2.53 \mathrm{e}+06$ & 73.8 & 0.23 & 0.063 \\
\hline BY-111 & 459 & 4.53 & $2.30 \mathrm{e}+06$ & 70.0 & 0.23 & 0.062 \\
\hline BY-112 & 291 & 9.44 & $2.93 \mathrm{e}+06$ & 72.0 & 0.23 & 0.062 \\
\hline C-108 & 66 & 2.62 & $2.92 \mathrm{e}+06$ & 72.8 & 0.23 & 0.069 \\
\hline C-109 & 66 & 2.62 & $2.92 \mathrm{e}+06$ & 75.8 & 0.23 & 0.071 \\
\hline C-111 & 57 & 2.35 & $2.96 \mathrm{e}+06$ & 74.0 & 0.23 & 0.069 \\
\hline C-112 & 104 & 3.77 & $2.78 \mathrm{e}+06$ & 77.0 & 0.23 & 0.077 \\
\hline T-107 & 180 & 6.08 & $2.49 \mathrm{e}+06$ & 64.0 & 0.22 & 0.060 \\
\hline 7 TX-118 & 347 & 1.14 & $2.72 \mathrm{e}+06$ & 68.0 & 0.22 & 0.059 \\
\hline TY-101 & 118 & 4.20 & $3.59 \mathrm{e}+06$ & 64.5 & 0.22 & 0.056 \\
\hline TY-103 & 162 & 5.53 & $3.42 \mathrm{e}+06$ & 66.8 & 0.22 & 0.055 \\
\hline TY-104 & 46 & 2.02 & $3.86 \mathrm{e}+06$ & 64.3 & 0.22 & 0.068 \\
\hline
\end{tabular}

a) Waste volumes from Hanlon (1993)

b) molecules $/ 100 \mathrm{eV}$ 
Table A-2. Gas Concentrations in Ferrocyanide Tanks.

\begin{tabular}{|l|c|c|c|c|c|c|}
\hline Tank & $\begin{array}{c}\text { Heat load } \\
(\mathrm{W})^{*}\end{array}$ & $\begin{array}{c}\text { Generation } \\
\text { rate (L/day) }\end{array}$ & $\begin{array}{c}\text { Max. } \mathrm{H}_{2} \% \\
\text { passive vent. }\end{array}$ & $\begin{array}{c}\text { Days to } \\
25 \% \text { LFL }\end{array}$ & $\begin{array}{c}\text { Max. } \mathrm{H}_{2} \% \\
50 \text { CFH } \\
\text { purge air }\end{array}$ & $\begin{array}{c}\text { Days to 25\% } \\
\text { LFL }\end{array}$ \\
\hline BX-102 & 974 & 12.8 & 0.10 & Never & 0.03 & Never \\
\hline BX-106 & 735 & 12.4 & 0.09 & Never & 0.03 & Never \\
\hline BY-103 & 1,612 & 18 & 0.16 & Never & 0.04 & Never \\
\hline BY-104 & 2,549 & 52.9 & 0.47 & Never & 0.12 & Never \\
\hline BY-105 & 2,549 & 46.4 & 0.48 & Never & 0.11 & Never \\
\hline BY-106 & 2,959 & 81.6 & 1.12 & 494 & 0.20 & Never \\
\hline BY-107 & 2,608 & 19.5 & 0.14 & Never & 0.04 & Never \\
\hline BY-108 & 2,696 & 39.1 & 0.27 & Never & 0.08 & Never \\
\hline BY-110 & 2,022 & 33.2 & 0.29 & Never & 0.07 & Never \\
\hline BY-111 & 1,612 & 12.9 & 0.12 & Never & 0.03 & Never \\
\hline BY-112 & 1,787 & 9.2 & 0.07 & Never & 0.02 & Never \\
\hline C-108 & 1,758 & 18.8 & 0.14 & Never & 0.04 & Never \\
\hline C-109 & 2,063 & 23.2 & 0.17 & Never & 0.05 & Never \\
\hline C-111 & 1,875 & 19.7 & 0.14 & Never & 0.04 & Never \\
\hline C-112 & 2,210 & 28.6 & 0.22 & Never & 0.06 & Never \\
\hline T-107 & 708 & 8.8 & 0.08 & Never & 0.02 & Never \\
\hline TX-118 & 1,403 & 6.3 & 0.05 & Never & 0.01 & Never \\
\hline TY-101 & 920 & 8.1 & 0.05 & Never & 0.02 & Never \\
\hline TY-103 & 1,057 & 9.6 & 0.06 & Never & 0.02 & Never \\
\hline TY-104 & 889 & 9.6 & 0.06 & Never & 0.02 & Never \\
\hline
\end{tabular}

a) from Crowe et al. (1993)

b) Not all of the tanks have continuous purge air. 
The maximum concentration for the worst tank, 241-BY-106, is 28 percent of the LFL. When instrument purge air is taken into account, the value is reduced to 5 percent of the LFL. The latter value for the volumetric concentration is consistent with the combustible gas samples taken under similar conditions in the ferrocyanide tanks.

Table A-3 shows the results of the calculations for a sealed tank (i.e., $Q=0$ ). The table shows that, with conservative radiolytic $\mathrm{G}$ values for $\mathrm{H}_{2}$, the conservative thermal generation from Meisel (1993), and no ventilation, the tanks require from 197 days to over 11 years to reach 25 percent of the LFL.

Table A-3. Days Required to Reach 25\% LFL for Sealed Tank.

\begin{tabular}{|l|c|c|c|}
\hline Tank & Heat load $(\mathrm{W})$ & $\begin{array}{c}\text { Generation rate } \\
(\mathrm{L} / \text { day })\end{array}$ & Days to $25 \% \mathrm{LFL}^{\mathrm{b}}$ \\
\hline BX-102 & 974 & 12.8 & 2,215 \\
\hline BX-106 & 735 & 12.9 & 2,341 \\
\hline BY-103 & 1,612 & 18 & 1,181 \\
\hline BY-104 & 2,549 & 52.9 & 253 \\
\hline BY-105 & 2,549 & 46.4 & 240 \\
\hline BY-106 & 2,959 & 81.6 & $197^{\mathrm{c}}$ \\
\hline BY-107 & 2,608 & 19.5 & 1,339 \\
\hline BY-108 & 2,696 & 39.1 & 592 \\
\hline BY-110 & 2,022 & 33.2 & 543 \\
\hline BY-111 & 1,612 & 12.9 & 1,568 \\
\hline BY-112 & 1,787 & 9.2 & 2,982 \\
\hline C-108 & 1,758 & 18.8 & 1,354 \\
\hline C-109 & 2,063 & 23.2 & 1,049 \\
\hline C-111 & 1,875 & 19.7 & 1,296 \\
\hline C-112 & 2,210 & 28.6 & 761 \\
\hline T-107 & 708 & 8.8 & 2,632 \\
\hline TX-118 & 1,403 & 6.3 & 4,100 \\
\hline TY-101 & 920 & 8.1 & 4,233 \\
\hline TY-103 & 1,057 & 9.6 & 3,367 \\
\hline TY-104 & 889 & 9.6 & 399 \\
\hline
\end{tabular}

a) Crowe et al. (1993)

b) Assumes Max. $\mathrm{H}_{2}$ concentration for passive breathing tank (Table A-2) is initial concentration.

c) Assumes 0 percent LFL initial concentration 


\section{REFERENCES}

Crowe, R. D., M. Kummerer, A. K. Postma, 1993, Estimation of Heat Load in Waste Tanks Using Average Vapor Space Temperatures, WHC-EP-0709, Westinghouse Hanford Company, Richland, Washington.

Crippen, M. D., 1993, Barometric Pressure Variations, WHC-EP-0651, Westinghouse Hanford Company, Richland, Washington.

Farley, W. G., 1991, Safety Assessment for Gas Sampling All Ferrocyanide Tanks, WHC-SD-WM-SAD-009, Rev. 2-A, Westinghouse Hanford Company, Richland, Washington.

Hanlon, B. M., 1993, Tank Farm Surveillance and Waste Status Summary Report for August 1993, WHC-EP-0182-65, Westinghouse Hanford Company, Richland, Washington.

Henrie, J. O., 1986, Hydrogen Control in the Handling, Shipping, and Storage of Wet Radioactive Waste, RHO-WM-EV-9, Rev. 1P, Rockwell Hanford Operations, Richland, Washington.

Kummerer, M., 1993, Safety Assessment for Interim Stabilization of Ferrocyanide Tanks, WHC-SD-SAD-018, Rev. 0, Westinghouse Hanford Company, Richland, Washington.

Meisel, D., C. D. Jonah, S. Kapoor, M. S. Matheson, and M. C. Sauer, 1993, Radiolytic and Radiolytically Induced Generation of Gases from Synthetic Wastes, ANL-93/43, Argonne National Laboratory, Argonne, Illinois.

Meisel, D., H. Diamond, E. P. Horwitz, C. D. Jonah, M. S. Matheson, M. C. Sauer, Jr., J. C. Sullivan, F. Bamabas, E. Cerny, and Y. D. Cheng, 1991, Radiolytic Generation of Gases from Synthetic Waste, ANL 91/41, Argonne National Laboratory, Argonne, Illinois.

Toth, J. J., P. G. Heasler, C. E. Willingham, P. D. Whitney, 1994, Organic Carbon in Hanford Single-Shell Tank Waste, PNL-9434, Pacific Northwest Laboratory, Richland, Washington. 
WHC-EP-0743

DISTRIBUTION

Number of Copies

ONSITE

4

U.S. Department of Energy-

Richland Operations Office

R. F. Christensen

R. E. Gerton

R. G. Harwood

DOE-RL Public Reading Room

Westinghouse Savannah River Company

R. D. Graves

H4-61

37

Westinghouse Hanford Company

H. Babad

S7-30

G. A. Barnes

H5-09

D. C. Board

S1-57

G. L. Borsheim

H5-27

R. J. Cash (3)

S7-15

G. T. Dukelow (3)

S7-15

G. L. Dunford

R2-50

K. D. Fowler (3)

R2-11

J. M. Grigsby

H4-62

K. D. Hein

R1-51

M. N. Islam

R3-08

G. D. Johnson

S7-15

N. W. Kirch

R2-11

D. B. Klos

S2-46

M. Kummerer

H4-62

J. M. McLaren

H0-34

J. E. Meacham

S7-15

T. L. Moore Sr.

H5-09

J. W. Osborne

R2-78

M. A. Payne

S7-15

R. S. Popielarczyk

R1-30

R. E. Raymond

R2-54

R. W. Reed

R1-51

C. P. Schroeder

L7-06 


\section{DISTRIBUTION}

Number of Copies

\section{CNSITE}

Westinghouse Hanford Company (continued)

Central Files

L8-04

Document Processing and

Distribution (2)

L8-15

Information Release

Administration (3)

A2-24

TFIC

R $1-28$ 

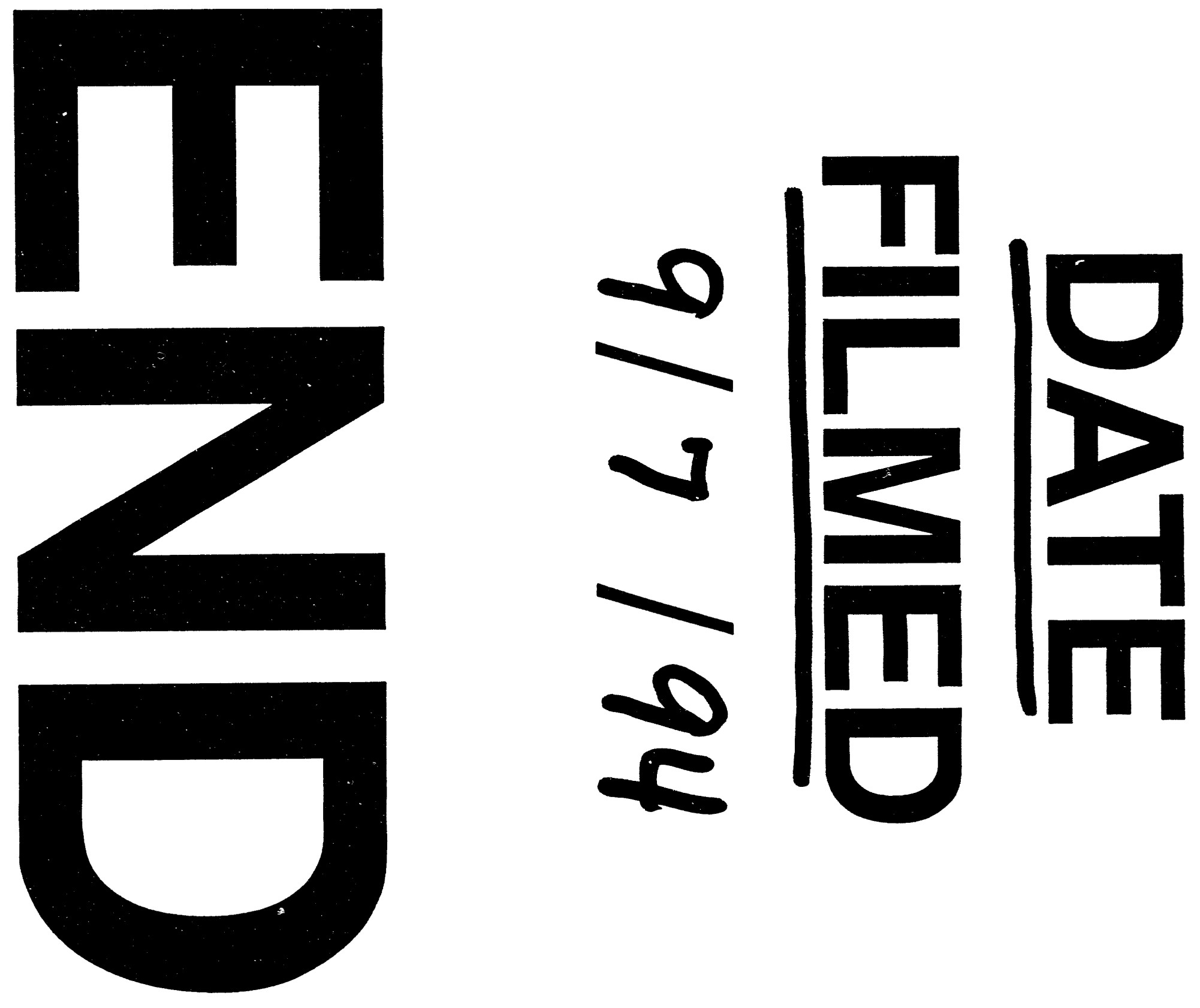
